\title{
Exploring Visual Mispronunciation at Segmental Level among EL 2 Chinese Students
}

\author{
Chao $\mathrm{Wu}^{1} \&$ Pan Wang ${ }^{1}$ \\ ${ }^{1}$ Nanchang Business College, Jiangxi Agricultural University, Jiangxi, China \\ Correspondence: Chao Wu, Nanchang Business College, Jiangxi Agricultural University, Jiangxi, China.
}

Received: September 2, 2020

Accepted: September 14, 2020

Online Published: September 24, 2020

doi: 10.5539/elt.v13n10p120

URL: https://doi.org/10.5539/elt.v13n10p120

\begin{abstract}
In our pronunciation courses, segmental level in English pronunciation plays a very important role in perception and teaching of English pronunciation. This research aims to investigate into the most salient pronunciation problems at segmental level by fresh college students from Mainland China through an experimental study, and it is found that the mismatches identified in the segmental level of English pronunciation are corresponded with the phonological features of the utterance of Chinese English. Moreover, in order to improve fresh college students' pronunciation and achieve the pronunciation of Standard English, some pedagogical implications and suggestions about teaching strategies are provided in this study which aimed at the most salient mismatches discovered in the research findings.
\end{abstract}

Keywords: English mispronunciation, segmental level, implications for teaching

\section{Introduction}

Chinese and English significant distinction even present in their phonological patterns. The phonological system of English involves two parts: segments and suprasegments. Segments involve individual vowels and consonants, and suprasegments consist of stress, pitch contour or intonation, rhythm (Seferoglue, 2005). While in Chinese, almost each character corresponds to a single syllable (Kelly, 2000), which may possess an onset of consonant(s) initially in the syllable and a nucleus consisting a vowel or two vowels or, in some cases, a vowel with a final nasal consonant(s). For example, /ta/, /tai/ and /tan/ are syllables with one consonant onset, while /wa/, /wai/ and /wang/ are ones with two-consonant onset. Specifically, when a /t/ or $/ \mathrm{d} /$ sound glides to a $/ \mathrm{j} /$ sound in a smooth and quick way, the two sounds seem to happen simultaneously with segment boundary and they would be coalesced into a new sound $/ \mathrm{t} \mathrm{f} /$ or $/ \mathrm{d} 3 /$ (Wang, 2005), Moreover, the absence of consonant onset is adopted in Chinese syllables as well: e.g., /a/, /e/, and /ai/ are common utterances of Chinese phoneme. In additional, another feature of a Chinese syllable is, generally, its four tones: level (tone 1), rising (tone 2), falling-rising (tone 3), falling (tone 4). In Chinese, a tone plays an important role in identified the meaning of Chinese characters (Zhao, 2006). For example, if phonemes /ti/ is labelled with the four different tones, then four different meanings will present. /tî// implies "kick", /tí/ "question", /tî̀/ "body" while /tî/ conveys the meaning of "substitute".

At the level of phonological, Gui (1978) has investigated the distinctions between Chinese and English, based on phonemes, tone, intonation, etc. Fan (1982) compared the sound patterns of Chinese and English. He (2002) and Wei (2003) made contrastive explored on Chinese and English word stress patterns. However, these contrastive studies are often met with criticism or challenged, although they manage to predict the possible transfer mismatches of language learners in L2, they are inappropriate to predict the mismatches learners make in actual learning contexts (Whitman \& Jackson, 1972). This article aims to categorize transfer errors in pronunciation due to Chinese L1's interference on English L2 through observing genuine teaching and learning contexts, which may not exhaust all transfer errors in this case but definitely will cause implications for English pedagogy in China. It is well known that Chinese EFL learners tend to confront some phonetic challenges in English pronunciation.

These challenges are connected with1) certain individual vowels and consonants which do not occur in Chinese or are pronounced differently in Chinese; 2 ) vowel combinations and consonant clusters which are not allowed by Chinese phonotactic limitations; 3 ) sound variations in forms of liaison, weak form, elision and assimilation 
in connected speech. Native Chinese EFL learners who cannot overcome these challenges find it hard to speak pure, native-like English.

Consequently, the segmental features of English speech, e.g. consonants, vowels, etc, play a crucial role in the speakers' correct utterance of English, which can be considered as the major elements in English language pronunciation. Moreover, there are still a large number of Mandarin speakers who are keen on studying English nowadays in China. In addition, with years' experience of English pronunciation teaching, the author has perceived it is worthwhile investigating the features of English pronunciation in segmental level by college students from Mainland China. So, the present study will

Table 1. Consonant phonemes of English. colored phonemes are not shared with Chinese

\begin{tabular}{|c|c|c|c|c|c|c|c|}
\hline $\mathrm{MOA}$ & $\begin{array}{l}\text { Both lip } \\
\text { /bilabial }\end{array}$ & $\begin{array}{l}\text { Lower lip and } \\
\text { upper teeth } \\
\text { /labiodental }\end{array}$ & $\begin{array}{l}\text { Tip of tongue } \\
\text { and teeth } \\
\text { /interdental }\end{array}$ & $\begin{array}{l}\text { Tip of tongue } \\
\text { and tooth ridge } \\
\text { /apicoalveolar }\end{array}$ & $\begin{array}{l}\text { Front of tongue } \\
\text { and hard palate } \\
\text { /laminopalatal }\end{array}$ & $\begin{array}{l}\text { Back of tongue } \\
\text { and soft palate } \\
\text { dorsovelar }\end{array}$ & $\begin{array}{l}\text { Throat } \\
\text { /glottal }\end{array}$ \\
\hline \multirow{2}{*}{ stops } & voiceless & $\mathrm{p}$ & & $\mathrm{t}$ & & $\mathrm{k}$ & \\
\hline & voiced & b & & d & & $\mathrm{g}$ & \\
\hline \multirow{2}{*}{ affricates } & voiceless & & & & ts & & \\
\hline & voiced & & & & ds & & \\
\hline \multirow{2}{*}{ fricatives } & voiceless & & $\theta$ & $\mathrm{s}$ & $\int$ & & $\mathrm{h}$ \\
\hline & voiced & & $\mathrm{v}$ & $\mathrm{z}$ & 3 & & \\
\hline nasals & $\mathrm{m}$ & & & $\mathrm{n}$ & & & \\
\hline lateral & & & & 1 & & & \\
\hline semivowels & $\mathrm{w}$ & & & $\mathrm{r}$ & $\mathrm{j}$ & & \\
\hline
\end{tabular}

Notes: POA and MOA refer to place of articulation and manner of articulation respectively.

give specific attention to the discussion of this problem in an experimental way. Hence, this paper detects the pronunciation errors at segmental level of ten college students who come from different parts of mainland China (Northeast, Central and Eastern China), and a sound experiment implements through acoustic phonetic software, praat. Furthermore, comparisons will also be made between perception and pronunciation experiment results because of the relationship between these two factors in the acquisition process. Hopefully this study will provide English teachers suggestions about teaching strategies aiming at the most salient problems while teaching English.

\section{Literature Review}

In recent years, there has been an increasing interest in pronunciation research. Pronunciation study has been dominated by a strong interest in quantitative investigations of the development of learners' proficiency as a result of inhabiting different learning environments (e.g., Díaz-Campos, 2004; O’Brien, 2003, 2004; Simões, 1996; Stevens, 2000) and teaching strategies by measuring specific phonological factors according to native-speaker standards (e.g., D. Macdonald, Yule, \& Powers, 1994). Few studies have thus far investigated the teaching and learning of pronunciation from the perspective of interference between L1 and L2. Many studies (Best, 1995; Best, McRoberts, and Goodell, 2001; Flege, 1995; Flege, Frieda, \& Nozawa, 1997; Gass and Selinker, 2001;) have confirmed that numerous elements can affect L2 speech production, such as the age of L2 acquisition, the length of residence in the L2 surrounding, motivation, and the amount of L1 usage. However, according to Flege's study (1995), L1's effect on L2 speech production is especially noteworthy.

As a result of the interference of habits from L1 onto L2 (Beardsmore, 1982), the difficulties facing a L2 learner involve phonology, vocabulary and grammar, those negative interference from the first language must be unlearned before acquiring new habits in the second language (Dualy, Burt, \& Krashen, 1982). Selinker (1983) claims that there are two types of transfer in acquiring a second language: positive and negative. The positive transfer of a native language pattern can take place where the two languages are partly identical or similar, but where they are different, learning challenges arise, and mismatches resulting from negative transfer are possible to occur (Ellis, 1994). As Odlin (1989) states, when negative transfer occurs, we can study learners of different native languages and make a comparison between them to find out the effect of L1 in learning a second language L2. This article aims to contrast Chinese L1 and English L2 with respect to their pronunciation in genuine teaching and learning contexts, so as to determine the underlying negative transfers and to classify the transfer 
mismatches in utterance production. The greater differences between two languages will result in a greater difficulty for learners (Hayati, 1998). With the perception distinctions in pronunciation between Chinese L1 and English L2, we may be able to improve students' English pronunciation by enhanced practice in the aspects concerned. So this paper sets out to investigate the segmental features of English pronunciation of college students from Mandarin speakers in Mainland China, in an attempt to offer teachers teaching strategies addressing the most acute pronunciation problems among college students.

\section{Participant}

Ten participants chosen randomly for this study are fresh students majored in English at Nanchang Business College, Jiangxi province. They are consists of 2 male and 8 female students with an age mostly in 18 and 19 years, all of them come from different provinces in the Southeastern, Eastern and Central part of China and take Mandarin as their mother tongue. Hence, they are chosen in this study for the research in whether their English pronunciation has been influenced by their L1, Mandarin Chinese, and whether their pronunciation shares similar acoustic features of English by Mandarin utterance from Mainland China. All ten participants were required to carry out the task of reading aloud a passage extracted from New Trend English Pronunciation Course by Liu Ming-Dong et al., 2018. The personal background information of ten participants can be described in Table 2 and they participated in all activities of audio data collection.

\section{Material}

All ten participants were invited to read aloud the same text extracted from a textbook named New Trend English Pronunciation and Intonation course by Liu Ming-Dong et al, published by the Commercial Press and their sound data was recorded. The following ten sentences were selected in this research as the material for in-depth analysis of participants' pronunciation features.

\section{S1. The soul is not where it lives at present, but where it loves.}

S2. She won the first prize in sailing competition, but at what price.

S3. Eat at pleasure, drink with measure, and you will become healthy.

S4. He remained loyal to the royal family after the painful revolution.

S5. But bad habits won't change without a lot of hard work, will they?

S6. The path to learning to speak a second language without an accent appears to be a combination of hard work, a good ear, and a strong desire to sound like a native speaker.

S7. You have some interesting idea in your composition, but your English needs polishing as usual.

S8. When the bell rang, the young boy ran straight out of the classroom without taking his schoolbags.

S9. Even though she is having her birthday on the fifteenth of October.

S10. We were all very worried about that old tourist in such a bad weather.

These ten sentences have been chosen because they involve some phonological features that are believed to be quite confusing ones for L1 Chinese to pronounce correctly e.g. $/ \delta / / \theta / / \mathrm{y} / / 3 /$ etc, and the reasons why the participants mispronounced those consonant phonemes frequently.

\section{Methods}

The recordings of the ten participants have been collected and their pronunciation is analyzed in details in terms of English segmental features by acoustic phonetic software, praat (Version 6.1.14). As there are some mismatches among participants' pronunciation and the native pattern, e.g. RP and GA and some utterances are mispronounced as well. Therefore, the error analysis was employed in this research. The transcription of the text on the speakers' recording is conducted and IPA symbols are used as a measurement to check whether the participants' pronunciation is correct or not. Some features involving vowels and consonants known to be problematic for many ESL learners can be detected through this process, and similarly common phonological features can be generalized in this approach by Mandarin speakers from Mainland China.

\section{Data Analysis}

The data was analyzed by identifying the mispronunciation patterns that are deviated from the correct pronunciation according to the International Phonetic Alphabet symbols and the most serious problems can be identified at the segmental level (consonants and vowels), as can be seen in Table 2 and 3. 
Table 2. Mismatches of the vowels and their features

\begin{tabular}{|c|c|c|c|}
\hline Vowels & Phrase 1 & Phrase 2 & Features \\
\hline$/ \mathfrak{m} / \rightarrow / \mathrm{e} /$ & S5: bad habit & S8: schoolbags & Shortening of diphthong \\
\hline$/ \mathrm{ei} / \rightarrow / \mathrm{e} /$ & S2: sailing & S4: painful & Shortening of diphthong \\
\hline$/$ ৩ə/ $\rightarrow / \mathrm{a} /$ & S7: usual & S10: tourist & Shortening of diphthong \\
\hline$/ \mathrm{eI} / \rightarrow / \mathrm{aI} /$ & S8: straight & & Shifting to a similar vowel \\
\hline$/ \mathrm{e} / \rightarrow / \mathrm{a} /$ & S1: present & & Shifting to a schwa \\
\hline$/ \Lambda / \rightarrow / \mathrm{a}: /$ & S8: young & S3: become & Shifting to a back vowel \\
\hline$/ æ / \rightarrow / \Lambda /$ & S8: rang & S8: ran & Shifting to a similar vowel \\
\hline
\end{tabular}

In Table 2, "S1, S2...S7" are adopted respectively representing "Sentence 1, Sentence 2 to Sentence 7" as already shown in material part. We can also find in Table 2 the most salient feature in terms of vowel can be the substitution of /æ/ with /e/ and the shortening of diphthong.

Table 3. Mismatches of the consonants and their features

\begin{tabular}{llll}
\hline consonants & Phrase 1 & Phrase 2 & Features of mismatch \\
\hline$/ \mathrm{d} / \rightarrow / \mathrm{d} /$ & S5: they & S9: though & Producing a similar sound in Chinese \\
$/ \mathrm{d} / \rightarrow / \mathrm{z} /$ & S5: without & S10: weather & Substituting a similar sound in Chinese \\
$/ \theta / \rightarrow / \mathrm{s} /$ & S6: path & S9: birthday & Substituting a similar sound in Chinese \\
$/ \mathrm{Z} / \rightarrow / \mathrm{r} /$ & S3: treasure & & Substituting with a retroflex sound \\
$/ \mathrm{Z} / \rightarrow / \mathrm{z} /$ & S7: usually & & Substituting with a voiced alveolar fricative /z/ sound \\
$/ \mathrm{J} / \rightarrow / \mathrm{s} /$ & S7: polishing & & Producing a similar sound in Chinese \\
$/ \mathrm{y} / \rightarrow / \mathrm{n} /$ & S8: rang & & Producing a similar sound in Chinese \\
$/ \mathrm{z} / \rightarrow / \mathrm{s} /$ & S2: prize & S7: composition & Substituting with a voiceless alveolar fricative sound \\
$/ \mathrm{l} / \rightarrow / \mathrm{n} /$ & S4: loyal & S6: language & Substituting with a voiced alveolar nasal sound \\
\hline
\end{tabular}

In Table 3, "S1, S2...S7" are adopted respectively representing "Sentence 1, Sentence 2 to Sentence 7"

as already shown in Material part. We can also find in Table 2 the most salient feature in terms of consonants can be the substitution of dental fricative using similar sounds in Chinese and the difficulty in discerning / $\mathrm{n} /$ and $/ \mathrm{y} /$, etc. Chinese has a set of sounds that are similar to English $/ \mathrm{J} /$, but it is not quite the same, there is nothing in Chinese that even similar to $/ \theta /$ or $/ \mathrm{d} /$ with their 'inter-dental' or tip of tongue flat against edge of teeth articulation.

\section{Findings \& Discussion}

\subsection{Replacement with a Similar Sound}

Among the pronunciation with the most mistakes for L1 Chinese of English learners, dental fricative sounds $/ \theta /$ and $/ ð /$ would be the ones that is fairly problematic for most of the participants. According to the recording of speech sound, most participants had frustration in pronouncing the correct sound of voiceless dental fricative $/ \theta /$ and its voiced counterpart $/ / /$, they adopting frequently the substitution strategy to do with a similar sound in Mandarin Chinese e.g. /s/ to substitute for the voiceless dental fricative sound / $/$ / in English. The voiced alveolar stop /d/ and voiced alveolar fricative / $\mathrm{z} /$ become the most common substitution for the voiced dental fricative sound /ð/, since these sounds are originated from Hanyu Pinyin. This finding is in agreement with Ho (2003, p. 144). Chang (2001) also pointed out that it is a shared problem among Mandarin Chinese speakers as both the /e/ and /ठ/ sounds do not occur in Chinese. Besides, Ho (2003) also stated the fact that there is a si in the Chinese pinyin transcript but not the voiceless $/ \theta /$ ".

The English consonant sounds that cannot be matched in Chinese speech sound also include voiced palatal fricative / $/$ and voiced velar nasal /y/, where participants in this study tend to use voiced alveolar fricative /z/ and voiced alveolar nasal $/ \mathrm{n} /$ respectively as their substitution, e.g. the word usually /'ju:.zu.ə.li/ is uttered as /'ju:.zu.ə.li/ and the word English /'inglif/ is pronounced as /'Inglif/.

Whereas for the vowels, there is no counterpart /æ/ sound in Mandarin Chinese, as Chang (2001) stated. It poses a great challenge to learn the phonetics of this sound for beginners learning English, especially adult learners. 
The participants in this study, therefore would naturally adopt the vowel /e/ as a substitution for /æ/. This is because there are lots of differences between the Chinese phonological system and the English counterpart, so there is no exact and corresponded sounds of these phonemes that can be matched in Mandarin Chinese. For this reason, the speakers usually find another similar sound in their native language for easier pronunciation of these phonemes (Hockett, 1972; Lado, 1957).

\subsection{Failure to Distinguish between Voiceless Consonants and Voiced Consonants}

As one of the major foreign language in China, English is an important course and also a necessary communication skill for Chinese students since they enter primary school. However, most of the college students who have learned English for over six years are still confused by the distinction between the voiced and voiceless consonants when pronouncing English. For example, they would substitute voiced alveolar fricative /z/ with its voiceless counterpart $/ \mathrm{s} /$ in producing as the word example or use voiced alveolar nasal $/ \mathrm{n} /$ as a substitution for voiced alveolar liquid /1/ in pronouncing the word language. This phenomenon traces back to the fact that L1 Chinese learners tend to transfer some of the sounds in Mandarin Chinese to English pronunciation for the ease of articulation and utterance. Nevertheless, this negative practice affects their correct pronunciation in English utterance and lead to phonological features of acoustic problems that are peculiar to Chinese learners.

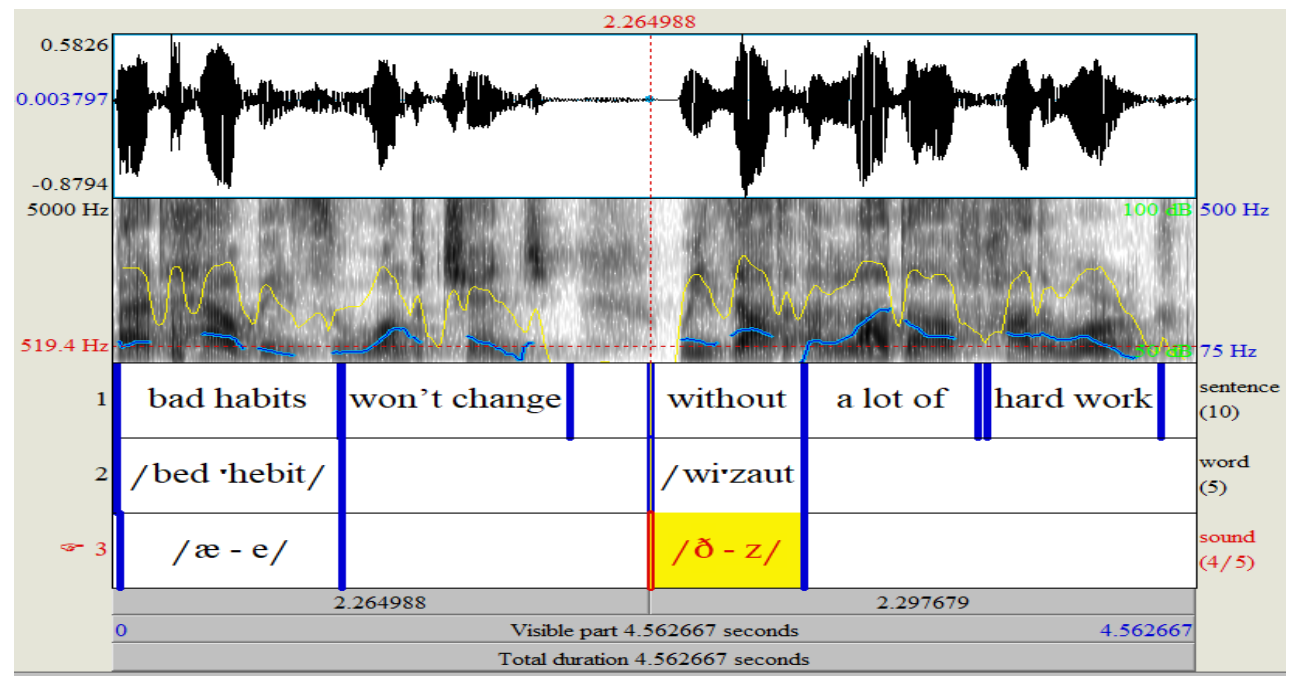

Figure 1. Chart of Spectrogram for S 5

In Figure 1, there are three tiers on the chart of spectrogram, the first one is the original sentence already shown in the material, the second is the recording sounds produced by participant and the third tier shows variations between the NE and the mismatches, Fig 1 shows that in the phrase bad habits, the front vowel /æ/ was pronounced as front vowel /e/ and the voiced dental fricative / $/$ in the word without was pronounced as voiced alveolar fricative /z/.

\subsection{Shortening the Diphthongs}

The case of shortening the diphthongs also occurs frequently in this reading aloud test. Examples can be found in the substitution of /ei/ with /e/. This is because of the fact that the utterance of diphthongs in Chinese is usually shorter and it needs smaller tongue and lip movement than their English counterparts. As a result, China English learners from Mandarin areas often mismatch of pronouncing the sounds of diphthongs as short as monophthongs, and there is no adequate distinction between the two component vowels (Chang, 2001). 


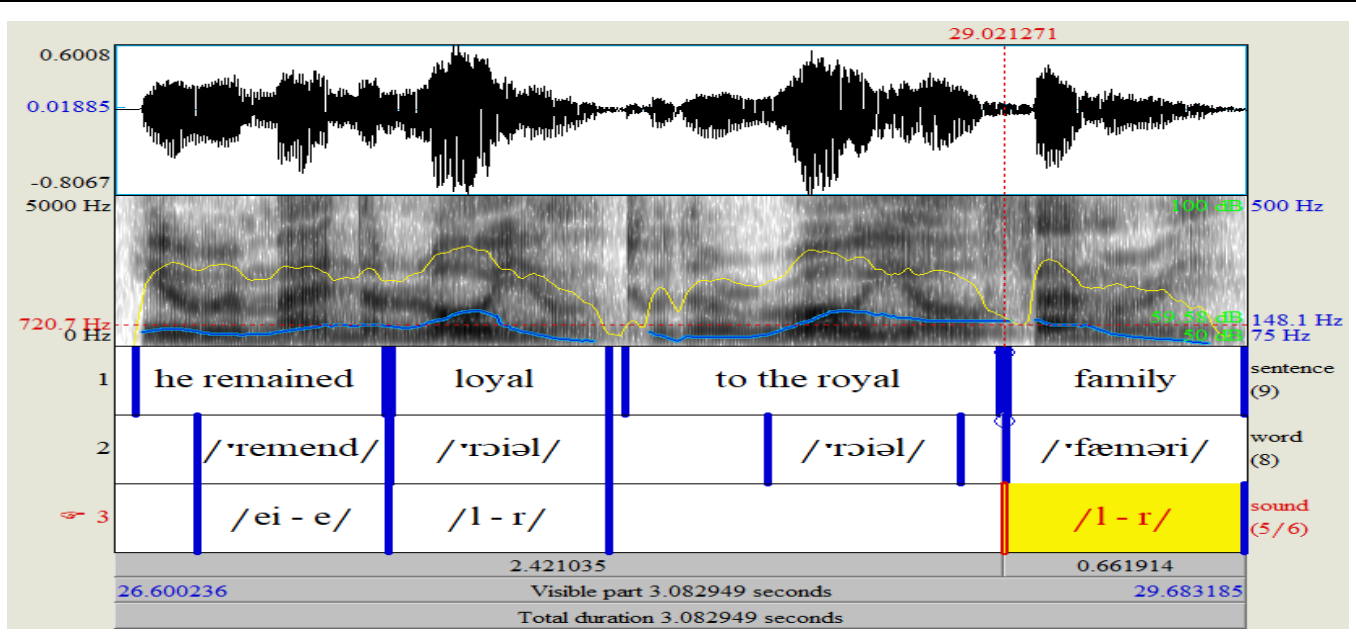

Figure 2. Chart of Spectrogram for S 6

Figure 2 shows that in word remained, the diphthong /ei/ was pronounced as single front vowel /e/, the voiced alveolar liquid / / was substituted obviously by the retroflex /r/ in the words loyal and family.

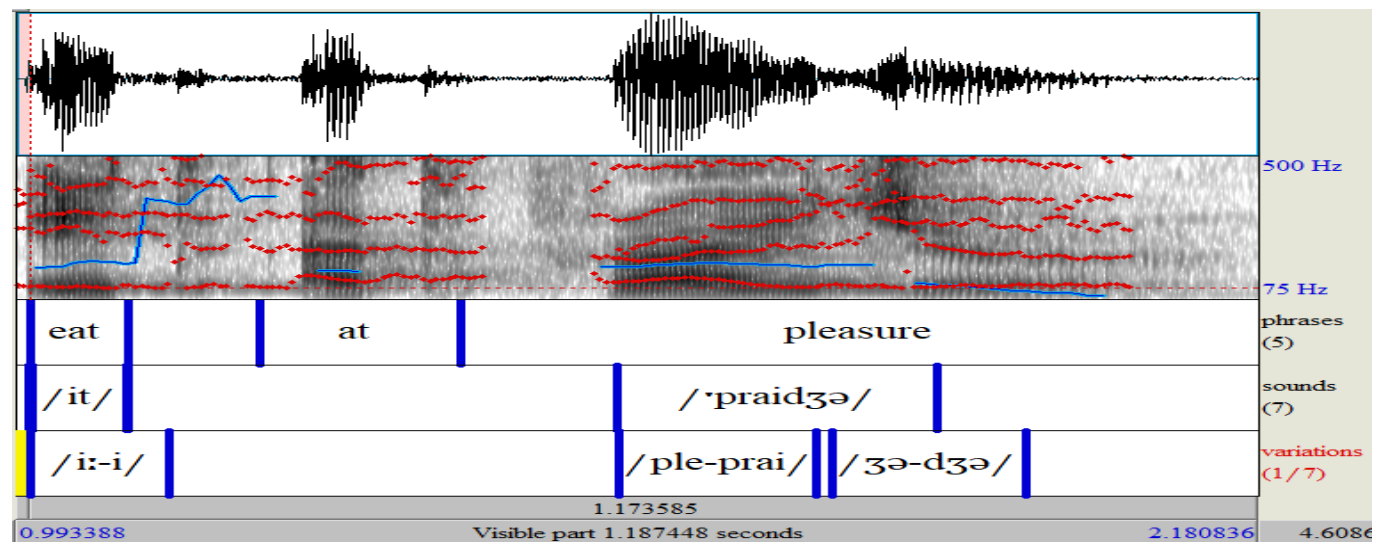

Figure 3. Chart of Spectrogram for S 3

In Figure 3 the long vowel /i:/ in the word eat was uttered as short vowel /i/, the word pleasure was produced as /praidzə/, while in Figure 4. sound /mezə/ was uttered as /meidzə/ in the word measure.

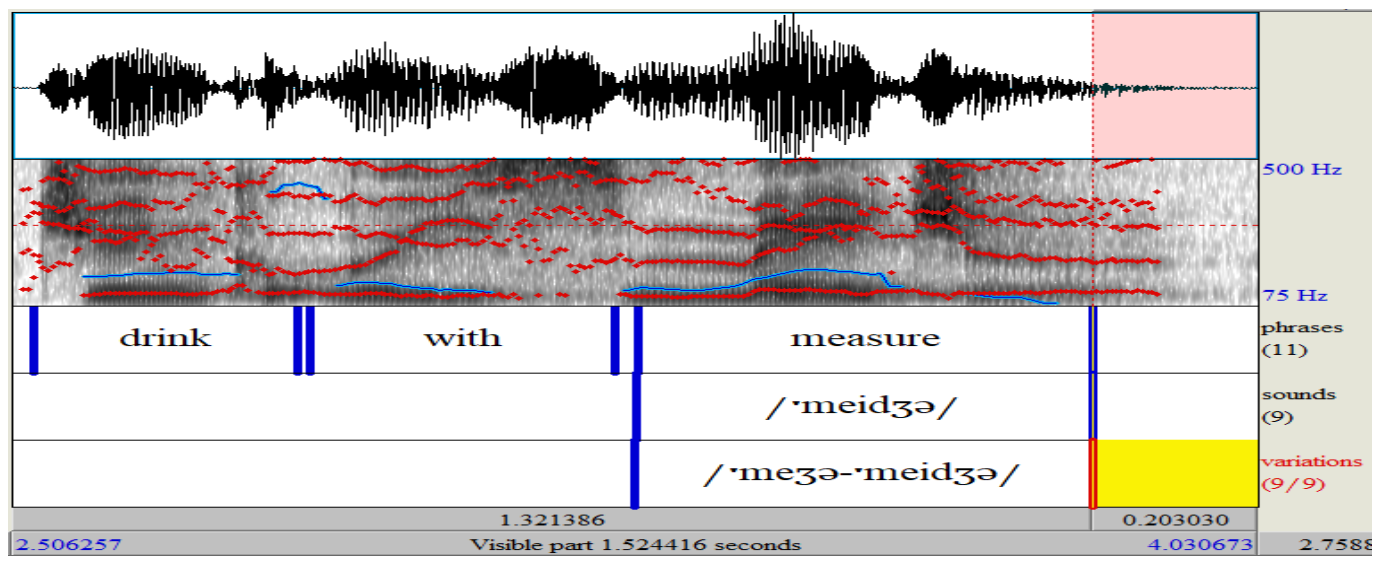

Figure 4. Chart of Spectrogram for S 3

Figure 4 is Chart of spectrograms for the utterance of sentence drink with measure produced by the research participant, diphthong /ei/ in the word measure was pronounced as short as monophthong /e/.

Figure 5. and Figure 6. are chart of spectrograms for the utterance of word ear and usual produced by native English speaker (NE) and the research participant, for the word ear, the diphthong /rə/ was pronounced as /eə/, and in Figure 6. the word usual was pronounced as /'ju:.zu.ə.li/, mismatched its original sound /'ju:.zu.ə.li/. 


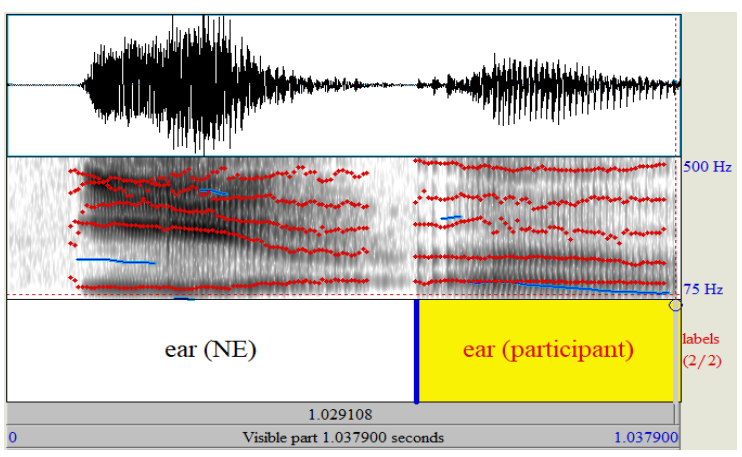

Figure 5. Chart of Spectrogram for word ear

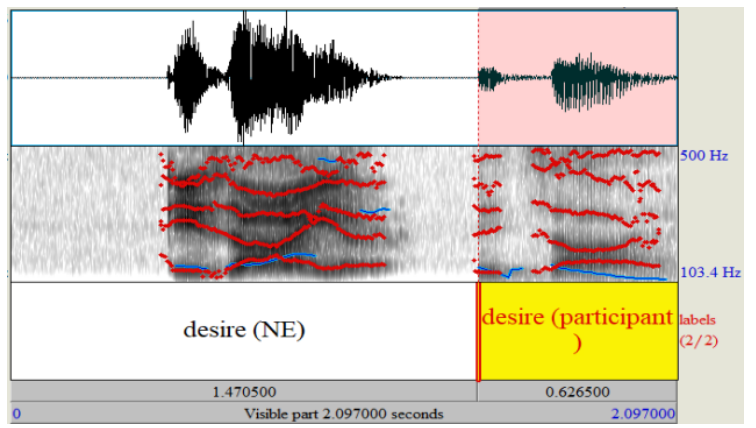

Figure 7. Chart of Spectrogram for word desire

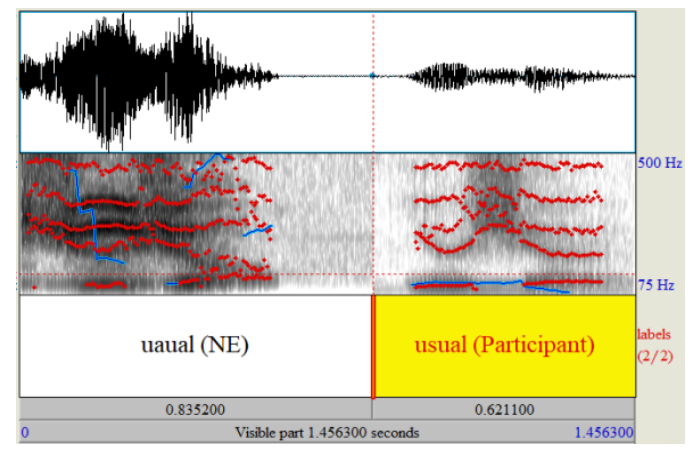

Figure 6. Chart of Spectrogram for word usual

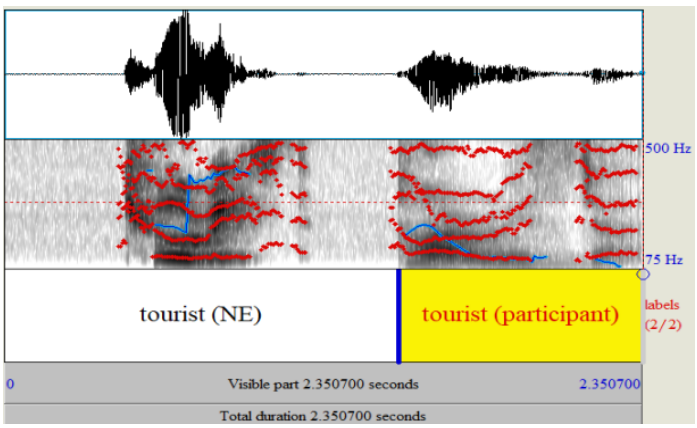

Figure 8. Chart of Spectrogram for word tourist

In Figure 7 the word desire was pronounced as /dı'zaıə(r)/, mismatched its original sound /dı'za:ə(r)/, and in Figure 8. the original sound /'toərist/ for tourist was pronounced as /'təorist/. All of four words are extracted from S6, S7, S6 and S10 respectively, errors of pronunciation can be told apart clearly from the spectrograms chart and distinctions between F0, F1, intensity and duration of vowel can also be clearly identified.

\section{Pedagogical Implication and Applications for Teaching}

This study aims at identifying the most problematic sounds with English segmental features by Mandarin speakers, and realizing the perception of teachers the most obvious pronunciation problems among Mandarin Chinese speakers. Furthermore, teaching and remedial instructions of these peculiar phonemes are also suggested in the hope of aiding students to pronounce sounds of words more effectively as well as correcting their mismatches. Therefore, the strategies adopted to improve Mandarin speakers' comprehensibility and their perception in English phonetics are highly-valued.

Pronunciation pattern drills could be adopted in order to deal with English pronunciation problems and to correct and improve the mismatches effectively. As Ho (2003, p. 149) stated, there are several useful strategies suggested by teachers in the CELC (Center for English Language Communication), in his study, e.g. teaching strategies are listed such as providing explicit phonetic instruction on the places and manners of articulation, encouraging students to identify errors of speech sounds, incorporating funny poems, drama into the articulation exercises to make pronunciation teaching meaningful and memorable and offering tongue-twisters exercises for students to teach them difficult sounds, etc. All these strategies help students pronounce English sound correctly and get awareness of comprehensibility of communication.

In this paper, the researcher will provide a kind of pronunciation teaching method focus on difficult sounds such as $/ \Theta /$ and $/ \delta /$ etc and teachers should provide students explicitly the manners and places of articulation. This explicit teaching strategy help students acquire a clear and concrete perception how the sound is actually pronounced, consequently, it would be easier for them to imitate and memorize the correct pronunciation as well. Moreover, lists of words that contain the various phonemes could be chosen as speech sound materials for students to discriminate between the correct sound and the similar sound which is pronounced by many Chinese students for substitution. For example, the "then/ðen/" and "zen/zen/" and the "sink/sin/" and "think/ery/". By contrasting the differences of pronunciation, students will come to realize the fact that whether they normally utterance is deviated from the correct pronunciation in accordance with the International Phonetic Alphabet 
symbol. Therefore, they can be trained a perception of whether their own pronunciation is correct or not. After that, students can obtain the comprehensibility of correct sound that teachers are reading aloud to them. At later stage, students are demanded to do some production tasks e.g. making a dialogue in pair work and being aware of the proper pronunciation of the target words that contain $/ \Theta /$ and $/ ð /$. By doing so, students can be trained to have a better perception of these peculiar sounds and therefore improve their phonetic accuracy of the difference sounds (e.g. / / / and / / / etc) among Mandarin Chinese students.

For other students that have already fossilized this mistakes, remedial instruction can be adopted by asking students "resetting your tongue on your teeth" and showing tongue position with diagrams.

\section{Conclusion}

This article is intended to achieve its aim to examine the specific pronunciation mismatches in terms of segmental level among Mandarin speakers from different parts of China as well as to identify the underlying interference that Chinese L1 may have on English L2, in the hopes of decreasing Chinese L1 negative transfer while acquiring English L2 pronunciation. The findings was well corresponded with the most obvious English segmental features among Mandarin Chinese speakers, such as use of substitution of $/ \mathrm{s} / \mathrm{for} / \mathrm{e} / \mathrm{d} / \mathrm{or} / \mathrm{z} / \mathrm{for} / \mathrm{d} /$ that appear very common among the errors made by Mandarin Chinese speakers. In other words, L2 learners usually substitute the L1 phones for similar L2 ones rather than create a new sound category, L2 learners substitute the closest L1 counterpart they can find. In terms of the phonological feature of vowels, the shortening of diphthongs, e.g. from /eI/ to /e/ is also very common for Mandarin speakers for greater ease in pronouncing words. According to this, the pedagogical implication and applicable suggestions were offered to English pronunciation teaching and some serious problems of English pronunciation are focused to deal with by Chinese speakers. Therefore, it is essential for an English teacher in China to have an accurate grasp of both the English and the Chinese phonological systems in order to enhance the quality of pronunciation as well as to lessen Chinese L1's interference on English L2. Through the contrastive analysis above, this article shows that some segmental and supra-segmental errors may occur to Chinese L1 students because of a lack of sounds or differences in speech production in Chinese. For an English teacher in China, having such knowledge can be quite advantageous, especially when the teacher desires to improve student pronunciation of English.

\section{Funding}

This research was funded by 2020 "13th Five-Year Plan" Project of Jiangxi Educational Science. (Project No: 20YB355)

\section{References}

Beardsmore, H. B. (1982). Bilingualism. Tieto: Avon.

Best, C. (1995). A direct realist view of cross-language speech perception. In W. Strange (Ed.), Speech perception and linguistics experience: Theoretical and mythological issues in cross-language speech research, 109(2), 775-794. Timonium, MD: York Press.

Best, C., McRoberts, G., \& Goodell, E. (2001). Discrimination of non-native consonant contrasts varying on perceptual assimilation to the listener's native phonological system. Acoustical Society of America, 109(2), 775-794. https://doi.org/10.1121/1.1332378

Chang, Y. (2001). A study of areas of English pronunciation which pose particular difficulties for Taiwanese EFL students based on the first students from two-year program of Trans world Institute of Technology. Journal Trans world Institute of Technology, 20, 95-108.

Díaz-Campos, M. (2004). Context of learning in the acquisition of Spanish second language phonology. Studies in Second Language Acquisition, 19, 1-16. https://doi.org/10.1017/S0272263104262052

Dulay, H., Burt, M., \& Krashen, S. (1982). Language two. New York: Oxford University Press.

Ellis, R. (1994). The study of second language acquisition. Oxford: Oxford University Press.

Fan, C. Z. (1982). Sounds of English and Chinese. Primary and Middle School English Teaching and Research, $1,3-4$.

Flege, J. (1995). Second language speech learning. In W. Strange (Ed.), Speech perception and linguistic experience: Issues in cross-language research (pp. 233-277). Timonium, MD: York Press.

Flege, J., Frieda, E., \& Nozawa, T. (1997). Amount of Native language (L1 use) affects the pronunciation of an L2. Journal of Phonetics, 25, 169-186. https://doi.org/10.1006/jpho.1996.0040

Gass, S., \& Selinker, L. (2001). Second language acquisition. Mahwah, NJ: Lawrence Erlbaum. 
Goodwin, J. (2001). Teaching pronunciation. In Celce-Murcis (Ed.), Teaching English as a Second Language (pp. 117-138). Heinle \& Hernle.

Gui, C. K. (1978). A comparison of Chinese and English sound system. Modern Foreign Languages, 1, 44-50.

Hayati, M. (1998). A contrastive analysis of English and Persian stress. Papers and Studies in Contrastive Linguistics, 34, 53-72.

He, S. F. (2002). Contrastive analysis of English and Chinese. Shanghai: Shanghai Foreign Language Education Press.

Kelly, G. (2000). How to teach pronunciation. Harlow: Longman.

O'Brien, M. G. (2003). Longitudinal development of second language German vowels (Unpublished doctoral dissertation). University of Wisconsin-Madison. Retrieved from ProQuest Dissertations and Theses (UMI No. 3089612).

Odline, T. (1989). Language transfer: Cross-linguistic influence in language learning. Cambridge: Cambridge University Press. https://doi.org/10.1006/jpho.1996.0040

Seferoglue, G. (2005). Improving students' pronunciation through accent reduction software. Brithish Journal of Educational Technology, 36(2), 303-316. https://doi.org/10.1111/j.1467-8535.2005.00459.x

Selinker, L. (1983). Language transfer. In S. Gass, \& L. Selinker (Eds.), Language transfer in language learning (pp. 33-68). Rowley, MA: Newbury House.

Simões, A. R. M. (1996). Phonetics in second language acquisition: An acoustic study of fluency in adult learners of Spanish. Hispania, 79, 87-95. https://doi.org/10.2307/345617

Stevens, J. J. (2000). The acquisition of L2 Spanish pronunciation in a study abroad context (Unpublished doctoral dissertation). University of Southern California. Retrieved from ProQuest Dissertations and Theses (UMI No. 3018129).

Wang, G. (2005, 2nd ed.). English Pronunciation \& Intonation for Communication-A Course for Chinese EFL Learners. Higher Education Press.

Wei, Z. C. (2003). An introduction to comparative studies of Chinese and English. Shanghai: Shanghai Foreign Language Education Press.

Whitman, R., \& Jackson, K. (1972). The unpredictability of contrastive analysis. Language Learning, 22, 29-41. https://doi.org/10.1111/j.1467-1770.1972.tb00071.x

Zhao, Z. D. (2006). Phonology. Shanghai Foreign Language Education Press.

\section{Copyrights}

Copyright for this article is retained by the author(s), with first publication rights granted to the journal.

This is an open-access article distributed under the terms and conditions of the Creative Commons Attribution license (http://creativecommons.org/licenses/by/4.0/). 